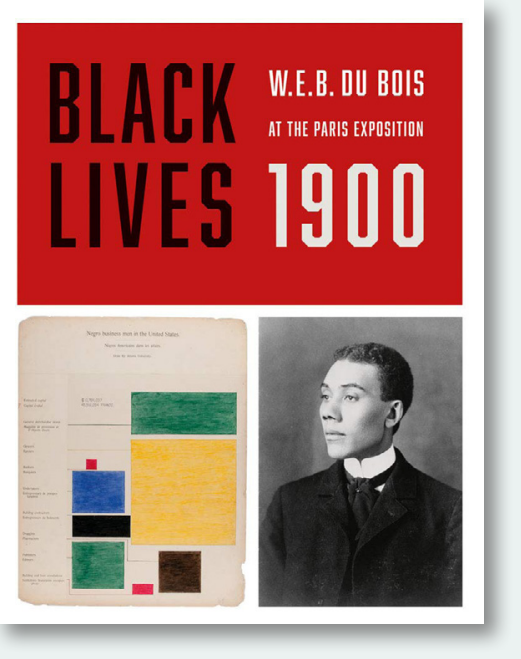

\title{
BLACK LIVES 1900: W. E. B. DU BOIS AT THE PARIS EXPOSITION
}

Edited by Julian Rothenstein

Redstone Press, 2019

144 pages

Hardcover: \$35.00, ISBN 978-1-942884-53-8

Review by: Krystle Harrell

Black Lives 1900: W. E. B. Du Bois at the Paris Exposition beautifully weaves together Du Bois's groundbreaking graphic visualizations with photographs of Black Americans post-slavery, to tell the little-known story of The American Negro Exhibit at the 1900 World's Fair. This oversized (12 3/4" $\times 10 ")$ and colorful reproduction of artifacts from the exhibit effortlessly immerses the reader in a visual record of Black lives just 35 years after emancipation. The book is divided into three chapters, the first of which focuses on Du Bois and provides a historical context of the exhibit. The other two chapters present the main sections of the exhibit: one illustrating the conditions of Black persons in the entire United States, and the other a case study of Black persons in Georgia, the state with the largest Black population at the time.

In the introduction, the historians Jacqueline Francis and Stephen G. Hall frame the historical context and importance of Du Bois's exhibit. They highlight the fact that as the 1800 s came to a close-fewer than 40 years since the ending of slavery - "the readily summoned image of the Black in the United States was that of an enslaved person..." (13). Herein lay Du Bois's motivation: to challenge this image. In just four short months following his commissioning by friend and attorney Thomas J. Calloway, Du Bois was able to create a triumphant display of "Black lives, in labor, worship, and leisure, at school, at work, and at home" (13). This achievement would not have been possible without his formidable, all-Black team including Booker T. Washington, librarian Daniel Murray, and numerous faculty members and students from Historically Black Colleges and Universities (HBCUs).

The authors explain that Du Bois's motivations and efforts to change the widespread image of Black people as inferior were not novel. Rather, he advanced the "program of displaying research in an aesthetic manner," which the abolitionists Fredrick Douglass and Sojourner Truth, and the educator Ida B. Wells initiated in the late 1800s (14). Just as Douglass and Truth tried to fight racist pseudoscience with studio portraits depicting "Black American achievement, agency," and subject matter, Du Bois continued the fight with his exhibit (14); going beyond photography, and introducing captivating infographics that were rooted in "demography, information science, and cartography" (14).

Francis and Hall go on to describe how Du Bois and his team used art as a way of telling the story of Black Americans, post-slavery. The works' vibrant color palette, basic geometric shapes, and hand-drawn graphics and maps stood out amongst the other exhibits portraying American life. This was important as they were situated in a back corner of the room, surrounded by "exhibits communicating the superiority of European nations" (16). To achieve their goals of countering the widespread stereotypes of Black Americans they had not only to draw in a wide audience, but they also had to keep that audience engaged with innovative data visualizations, ensure everyone could understand the exhibit by offering all the statistical charts in both French and English, and humanize Black 
Americans by comparing their demographics to those of Europeans. Even though the message and success of the exhibit-which earned numerous accolades and medals at the exposition-were widely ignored by the White American press at the time, it is brought back to life between the covers of this book.

After Francis's and Hall's contextualization of the exhibit within the realms of art and history, there is a short note from the prominent American historian and Harvard Professor, Henry Louis Gates, Jr., regarding the photographs included in the exhibit. Gates explains that although Du Bois is best known for his literary contributions, this exhibit allowed him to explore his love of photography, and that in doing so, he launched the first Black American international media campaign. Du Bois waged a battle in the war of representation by interweaving the beautiful and elegant photographs of Black Americans with the engaging, modernist data visualizations of Black demographics. Thus, he actively countered the common "Sambo" and "Picaninny" images of Black Americans and conveyed their success, dignity, and joy in a way no statistical graph could.

The inclusion of a timeline in the first chapter further underscores the timeliness of the 1900 American Negro Exbibit. Ranging from 1847 to 1910, the timeline highlights key dates in history that impacted Black American lives, as well as events that likely underpinned Du Bois's activist motivations. These include his first experience with Jim Crow laws in 1885, becoming the first African American to earn a Ph.D. from Harvard in 1895, and publishing The Philadelphia Negro: A Social Study in 1899. The Philadelphia Negro was one of Du Bois's most significant early works in sociology and laid the groundwork for him to lead the 1900 exhibit showcasing Black American life on a global stage.

As America experiences a reckoning with the ever-relevant fact that its promises are not fulfilled equally, Du Bois's words, and his extraordinary efforts towards The American Negro Exhibit serve as a reminder of the power of visual and oral communication in the continued effort to realize social justice. In the first chapter, Julian Rothenstein, the book's editor, subtly highlights the applicability of Du Bois's work to the present day by thoughtfully interspersing the timeline and photographs with carefully selected excerpts of his literary works. In his version of $M y$ Country 'Tis of Thee, Du Bois uses this well-known song to address the deep flaws in the American nation and to give the Black American-who may struggle with honoring a country in which they "do love its ideals if not all of its realities"-a way out of feeling "boorish, or ungracious" (31). In this work, Du Bois evokes the pain of slavery's history as well as the hopefulness to be found in true freedom and equality, just as he subtly acknowledged American oppression while spotlighting Black achievement throughout the exhibit. Modern exhibits like those at the National Museum of African American History and Culture, and the National Memorial for Peace and Justice, provide poignant representations of Black American achievement and oppression. Such exhibits continue the efforts of Du Bois and his team to use empirical evidence and immersive visualization to rebuke long-held ideas of Black persons as inferior and to celebrate the contributions of Black persons to America.

In the remaining chapters, "A Nation Within A Nation" and "The Georgia Negro: A Social Study," readers are introduced to the stunning infographics and captivating photography of the exhibit. Here, Rothenstein allows the maps, charts, and photographs to tell their own story, save for small, identifying captions on the photographs. Each reproduction draws the reader in with its exciting colors, mesmerizing shapes and graphics, and striking portraits of Black Americans in their everyday lives.

The second chapter, "A Nation Within A Nation," introduces the first series of graphics from the 1900 exhibit, entitled, $A$ Series of Statistical Charts Illuminating the Condition of the Descendants of Former African Slaves Now in Residence in the United States of America. In the first of two maps in the series, Proportion of Negroes in the Total United States, he compares the Black American population to the entire US population from 1800 to 1890, in 30-year increments. The second map similarly compares the Black American population to the total population of various European countries, using proportionally sized national outlines and population totals. In both maps, Du Bois uses color and size proportions to portray Black Americans as a "small nation of people" within the larger US nation, with a population size comparable to other nations ( $\mathrm{Du}$ Bois 1900). Du Bois quietly undercuts the idea of Black persons as an insignificant or negligible component of either the United States or the world as a whole.

Also included in the chapter are twenty-two infographics that illustrate the demographics of this "Nation within a 
Nation.” In many of these data portraits Du Bois evoked new and interesting ways of visualizing demographic data, including a unique square-spiral used to show the disparity between Black Catholics and Black Protestants (14,517 vs. $2,659,460)$, the interesting use of proportional symbols to indicate the distribution of Black businessmen across the trades, and the color choices of black to brown to yellow in his illustration The Amalgamation of the White and Black elements of the population in the United States, depicting the striking increase in the number of biracial Americans from 1800 to 1890 .

By breaking down such things as the change in the proportion of slaves to Black freemen, Black property valuation, Black landholders and businessmen, and the number of Black teachers and children in the public school system, Du Bois empirically characterizes the Black population as successful and determined. All of this success was achieved despite the numerous obstacles they faced following emancipation, including harsh Jim Crow laws and separate-but-equal provisions. In the final data portrait of the section, The Rise of the Negroes from Slavery to Freedom in One Generation, Du Bois explicitly highlights the progress of Black Americans in the face of oppression since 1860, stating, "In 1890 nearly one fifth of them owned their own homes and farms. This advance was accomplished entirely without state aid, and in the face of proscriptive laws" (84).

The second series in the exhibit, The Georgia Negro: $A$ Social Study, is laid out in the final chapter, with an additional twenty-two data portraits and maps. The section opens with a map in which Du Bois illustrates the routes of the African slave trade, and makes his famous proclamation, "The problem of the twentieth century is the problem of the color-line" (86). Du Bois employs various cartographic techniques in the eight maps found in the series to illustrate the distribution of Black Americans in the United States, within Georgia, and their migration patterns to and from Georgia. Interspersed amongst the maps and photographs of the series are unique data portraits including the mesmerizing spiral graph depicting Assessed Value of Household and Kitchen Furniture Owned by Georgia Negroes, and the bullseye-spike combination used to illustrate Assessed Valuation of All Taxable Property Owned by Georgia Negroes.

The final data portrait, Valuation of Town and City Property Owned by Georgia Negroes, best frames Du Bois's narrative of Black Americans achieving success despite oppression. The simple line graph, depicting a general increase in Black property valuation from 1870 to 1900 , is juxtaposed against the placement of text describing societal events including, "Political Unrest" in the late 1870s, or "Lynching" and "Disfranchisment and Proscriptive Laws" in the 1890s. These societal events underscore the oppression Black Americans faced following emancipation, while the solid black line soaring to the top of the graph illustrates their determination to be successful free Americans. The simplicity of this data portrait contributes to the clarity of Du Bois's narrative; the entirety of the exhibit can be summed up by this one visualization: Black success in the face of oppression.

By thoughtfully placing photographs near related infographics, Rothenstein achieved a balance between the empirical evidence and visual evidence in retelling Du Bois's story of the successful Black American. However, though the distribution of the photographs, data portraits, and maps were much appreciated, at times it seemed to make the second series appear disjointed. Specifically, the maps of Negro Population of Georgia by Counties: the years 1870 and 1880 appear on page 111, but the map of the 1890 population distribution is not displayed until page 134 . Based on the handwritten numbers on the reproductions, it appears they are meant to be seen in sequence, and this separation in the book makes it difficult to compare the distribution changes across the period.

The book closes with Rothenstein quoting the modern author Ta-Nehisi Coates, who characterized the modern backlash toward Black success as holding that "the presentation of Black people as normal in their sort of bourgeois, everyday, easily integratable manner into America-actually was an attack on whiteness and white supremacy. .." (137). In point of fact, Du Bois's presentation of Black achievement in 1900 was indeed an attack on white supremacy and could well be seen as constituting the first salvo in the war that wages on today-in social media and elsewhere. This book is a timely reminder of what Black Americans can achieve in the face of oppression, as well as a somber reminder that even though "the twentieth century" is over, "the problem of the color line" is not yet solved.

As we look to retell history and include more stories of Black American and minority success, this compilation of the artifacts from Du Bois's 1900 American Negro Exhibit provides a timely historical perspective of the post-slavery advancements of Black Americans. Though there 
have been recent compilations of the data portraits themselves (editor's note: see CP 93 for a review of one such book), Rothenstein goes beyond the data, presenting the entirety of the story by including the historical events leading up to the exhibit, the novel data visualizations, and the immersive photography portraying the everyday lives of Black Americans. The efforts of Rothenstein-along with David Adjaye (Forward), Jacqueline Francis and Stephen G. Hall (Introduction), and contributor Henry Louis Gates, Jr.combine to create a beautiful book of art and history. This collection is fit for display on any coffee table, and not just hidden on a bookshelf.

\section{REFERENCE}

Du Bois, W. E. Burghardt. 1900. “The American Negro at Paris." The American Monthly Review of Revierws 22 (5): 575-577. 